\section{Clozapine treatment for schizophrenia-related polydipsia}

\section{Tratamento com clozapina da polidipsia relacionada à esquizofrenia}

Dear Editor,

Psychogenic polydipsia occurs in 2-3\% of patients with schizophrenia and may lead to severe clinical complications such as hyponatremia, convulsions, and death. Despite its potential morbidity, polydipsia in schizophrenic patients has not been the subject of controlled clinical investigations to date. As a result, treatment options for this condition are scarce and the evidence on their efficacy is weak. ${ }^{1,2}$

Clozapine has been proposed as a possible therapeutic alternative based on a few case reports. ${ }^{1}$ However, in a recent study investigating the effects of clozapine and haloperidol in an animal model of psychogenic polydipsia induced by quinpirole, haloperidol showed superior efficacy in reverting polydipsia. ${ }^{3}$

Contrasting with the finding based on the animal model, we describe the case of a patient who developed psychogenic polydipsia while in use of haloperidol and olanzapine and who had a marked improvement of these symptoms after clozapine was initiated.
$A B$ was a 33 year-old man with a history of 15 years of hebephrenic schizophrenia and no previous history of psychogenic polydipsia according to the reports of relatives and care takers. $\mathrm{He}$ was admitted to our clinic due to episodes of agitation and vomiting, as reported by a nurse from the institution where the patient lives. He had been on olanzapine $20 \mathrm{mg}$ per day and haloperidol $10 \mathrm{mg}$ per day for the previous three months. At admission, he presented a BPRS score of 39 points and PANSS scores of 61 in the general psychopathology scale, 15 in the positive scale, and 47 in the negative scale. During his stay, we observed that episodes of agitation and vomiting initiated after exaggerated water intake. At one point, the patient's sodium serum level reached $130 \mathrm{mg} / \mathrm{dL}$ (normal range: 135-155). Attempts to keep the patient from taking water resulted in severe agitation requiring pharmacological interventions to avoid aggressiveness. $\mathrm{AB}$ also presented severe akathisia refractory to treatment with benzodiazepines and anticholinergics. In a previous hospitalization at the same clinic, the patient presented akathisia while on olanzapine monotherapy, with no further worsening after the addition of haloperidol, according to chart reports.

Haloperidol was tittered down and, after its suspension olanzapine was tittered down while clozapine was started and tittered up at a rate of $25 \mathrm{mg}$ every two days. $\mathrm{AB}$ presented with a marked improvement of both psychogenic polydipsia and akathisia with dosages as low as $100 \mathrm{mg}$ per day of clozapine. At $150 \mathrm{mg}$ per day of clozapine, BPRS scores had decreased to 23 and PANSS scores to 38,9 , and 32 in the general psychopathology, positive scale, and negative scale, respectively.

This case report gives further support to the use of clozapine when psychogenic polydipsia evolves in schizophrenic patients. It is possible that the quinpirole-induced polydipsia does not mimic 
what happens in schizophrenic patients suffering from polydipsia. Therefore, controlled clinical investigations evaluating the effects of clozapine in the treatment of polydipsia are still warranted.

\section{Juliana Belo Diniz, Quirino Cordeiro}

Department and Institute of Psychiatry, Universidade de São Paulo (USP) Medical School, São Paulo, SP, Brazil
Stevin Zung

Department and Institute of Psychiatry, Universidade de São Paulo (USP) Medical School, São Paulo, SP, Brazil Hospital João Evangelista, São Paulo, SP, Brazil

\section{Disclosures}

\begin{tabular}{|c|c|c|c|c|c|c|c|}
\hline $\begin{array}{l}\text { Writing group } \\
\text { member }\end{array}$ & Employment & $\begin{array}{l}\text { Research } \\
\text { grant }^{1}\end{array}$ & $\begin{array}{c}\text { Other research grant or } \\
\text { medical continuous } \\
\text { education }\end{array}$ & $\begin{array}{l}\text { Speaker's } \\
\text { honoraria }\end{array}$ & $\begin{array}{l}\text { Ownership } \\
\text { interest }\end{array}$ & $\begin{array}{l}\text { Consultant/ } \\
\text { Advisory } \\
\text { board }\end{array}$ & Other $^{3}$ \\
\hline Juliana Belo Diniz & $\begin{array}{c}\text { IPq- } \\
\text { HCFMUSP }\end{array}$ & $\begin{array}{l}\text { FAPESP** } \\
\text { CNPq }^{* *} \\
\text { Novartis* }^{*}\end{array}$ & - & - & - & - & - \\
\hline Quirino Cordeiro & $\begin{array}{c}\text { IPq- } \\
\text { HCFMUSP } \\
\text { Hospital João } \\
\text { Evangelista }\end{array}$ & - & - & - & - & - & - \\
\hline Stevin Zung & $\begin{array}{c}\text { Hospital João } \\
\text { Evangelista }\end{array}$ & - & - & - & - & - & - \\
\hline
\end{tabular}

* Modest

** Significant

*** Significant: Amounts given to the author's institution or to a colleague for research in which the author has participation, not directly to the author

Note: IPq-HCFMUSP = Instituto de Psiquiatria, Hospital das Clinicas, Faculdade de Medicina, Universidade de São Paulo; FAPESP = Fundação de Amparo à Pesquisa do Estado de São Paulo; CNPq = Conselho Nacional de Desenvolvimento Científico e Tecnológico.

For more information, see Instructions for Authors.

References

1. Brookes G, Ahmed AG. Pharmacological treatments for psychosis-related polydipsia. Cochrane Database Syst Rev. 2006;18(4):CD003544.

2. Dundas B, Harris M, Narasimhan M. Psychogenic polydipsia review: etiology, differential, and treatment. Curr Psychiatry Rep. 2007;9(3):236-41.
3. Amato D, Stasi MA, Borsini F, Nencini P. Haloperidol both prevents and reverses quinpirole-induced nonregulatory water intake, a putative animal model of psychogenic polydipsia. Psychopharmacology (Berl) 2008;200(2):157-65. 